\title{
Kajian Demokrasi Dan Islam Dalam Pandangan Abdullahi Ahmed An-Na'im
}

\author{
Fahmi Assulthoni \\ STAI Miftahul Ulum Pamekasan \\ soulelousa@gmail.com
}

\begin{abstract}
Abstrak
Democracy often become ' victims ' of some dissatisfaction among internal impingement Muslims in administering a legitimate Government. Democracy is a Western product may be very weak basic law. He is deemed to have no religious dimension at all, even look does not correspond to what is taught by Islam in the process of implementation of the system of Government. Many more assumptions assumptions are less responsive and based on the basic law. This is confirmed by the figures of moderate Muslims who argued that Islam and democracy is indeed a unity that can not be separated. Both have ties dahir and inner when adopted as a central system running. Democracy is Islam, and Islam is democracy.
\end{abstract}

Keyword: Demokrasi, Islam, Abdullahi Abmed An-Na'im

\section{Pendahuluan}

Demokrasi sesungguhnya tidak lagi menjadi barang baru bagi sebagian besar masyarakat di seluruh dunia. Isu berkaitan dengan demokrasi telah menjadi isu global, di setiap tingkatan jenjang pendidikan terutama bagi negara Indonesia selalu memuat materi berkaitan dengan demokrasi. Hal ini bertujuan untuk memberikan pemahaman sedini mungkin bagi masyarakat mengenai pentingnya pelaksanaan demokrasi dalam praktek kehidupan berbangsa dan bernegara. Namun yang disayangkan oleh penulis dalam hal ini ialah minimnya literasi mengenai konsep dan praktek demokrasi dalam Islam, kita hanya menemukan konsep demokrasi dari dunia Barat.

Sedikitnya kajian tentang demokrasi dalam literasi Islam menjadikan beberapa kalangan internal umat Islam terlanjur menolak sistem demikian. Kelompok ini memiliki anggapan bahwa Islam tidak mengenal konsep demokrasi. ${ }^{1} \mathrm{Hal}$ ini sangat mungkin terjadi disebabkan bibit-bibit demokrasi muncul dan dikembangkan negara Barat yang dicap tidak sejalan dengan nafas Islam. Mereka juga beranggapan bahwa dalam Islam suara seorang bodoh jelas

\footnotetext{
${ }^{1}$ Masdar Hilmy, Islamism and Democracy in Indonesia: Piety and Pragmatism (Singapore: ISEAS, 2010). 
tidak sama dengan suara seorang berilmu. Suara seorang pelacur jelas tidak sama dengan suara seorang ulama. ${ }^{2}$

Selain alasan di atas jika dilakukan sebuah penelusuran mendalam, maka akan didapatkan sebuah ruang kosong antara dimensi spiritualitas dengan penguatan demokrasi. Di antara keduanya terdapat kesenjangan, di mana masing-masing tidak memiliki ikatan dan hubungan, bahkan cenderung memiliki dunianya masing-masing. ${ }^{3}$

\section{Islam, Politik, Demokrasi: Three in One}

Agama (Islam) jika disandingkan dengan demokrasi tampak seperti dua kutub yang selalu bertolak belakang. Agama yang berada pada dimensi spiritualitas dianggap harus selalu berorientasi pada urusan-urusan akhirat. Di sisi lain, demokrasi telah dianggap sebagai kegiatan duniawiyah dan tidak memiliki hubungan 'spesial' apapun dengan agama. Kebanyakan manusia berasumsi bahwa kedua hal di atas tidak ada keterkaitan dan keterikatan satu sama lain. Sehingga tidak ada alasan untuk keduanya saling mencampuri dan masuk ke urusan masing-masing.

Kondisi demikian pada tahap selanjutnya menyebabkan panggung demokrasi tercerabut dari dimensi spiritualitas. Sebaliknya, dunia spiritualitas tidak mampu menjangkau dan memberikan pencerahan dan bimbingan terhadap panggung demokrasi. Hal tersebut menjadi refleksi dan representasi dari sekularisme yang dicirikan oleh pemisahan antara panggung demokrasi dan dunia spiritualitas. ${ }^{4}$

Demokrasi secara bahasa berarti pemerintahan oleh rakyat (rule by the people), dan ini akan berbeda dengan pola pemerintahan apapun yang legitimasinya tidak berasal dari pilihan rakyat. Amerika mengartikan demokrasi dalam orasi presiden Abraham Lincoln (1809-1865) yaitu: "pemerintahan rakyat, oleh rakyat, dan untuk rakyat". Praktek sistem pemerintahan seperti itu menjadi menarik jika kemudian dihubungkan dengan Islam. Hal ini dikarenakan tidak hentinya penilaian Barat terhadap Islam dan semua yang berkaitan dengan Islam, termasuk juga demokrasi.

Dalam konteks ini, Islam sebagai suatu kekuatan politik memiliki peluang besar untuk menggali kaidah-kaidah yang bernuansa demokratis, dan di situlah kiranya dapat dilihat hubungan antara Islam dan demokrasi. Dalam proses pengembangan demokrasi di dunia Islam inilah muncul nama an-Na'im

\footnotetext{
${ }^{2}$ Fauzan Al-Anshari, Presiden Indonesia untuk Penegakan Syari'at Islam (Jakarta: Panitia Persiapan Kepemimpinan Nasional, 2007), 58.

${ }^{3}$ Masdar Hilmy, Islam, Politik \& Demokrasi (Surabaya: Imtiyaz, 2014), 218.

${ }^{4}$ Ibid.

5 Sadek Jawad Sulaiman, Demokrasi dan Syura dalam wacana Islam Liberal, Pemikiran Islam Kontemporer tentang Isu-isu Global (Jakarta: Paramadina, 2003), 125.
} 
yang mencoba memberikan penalarannya. Pandangannya diharapkan menjadi penyegaran bagi umat Islam lainnya untuk senantiasa melihat sesuatu hal dari aspek positifnya, sehingga Islam tidak terkesan kaku dan menolak hal-hal baru. Dengan demikian, tulisan ini bermaksud untuk menelusuri hubungan antara demokrasi dan Islam yang kemudian dilihat dari kacamata seorang tokoh muslim, yaitu Abdullahi Ahmed An-Na'im.

Sebelum menelusuri arah pembahasan nisbah yang dimaksudkan di atas, perlu diketahui bahwa demokrasi yang difokuskan disini tidak menjelaskan wacana tersebut secara jami' mani'. Demokrasi yang dimaksud disini dapat dimengerti sebagai suatu kesetaraan politik, dan perimbangan kekuasaan. Sedangkan Islam sendiri berposisi lebih dari sekedar ideologi saja, namun juga memiliki kekuatan dan keterkaitan dengan sistem pemerintahan seperti demokrasi. Maka untuk dapat mengetahui bagaimana hubungan antara Islam dengan sistem demokrasi perlulah pembahasan masing-masing tersebut, kemudian berusaha untuk menarik sebuah kesimpulan tentang adanya hubungan antara Islam dan demokrasi.

\section{Islam ditinjau dari Aspek Politis}

Menurut Aristoteles, politik adalah usaha yang ditempuh warga Negara untuk mewujudkan kebaikan bersama, sedangkan secara umum pengertian atau definisi dan makna politik yaitu sebuah tahapan dimana untuk membentuk atau membangun posisi-posisi kekuasaan di dalam masyarakat yang berguna sebagai strategi mengambil keputusan-keputusan yang terkait dengan kondisi masyarakat.

Memandang Islam sebagai suatu kekuatan politik memberikan pemahaman bahwa Islam mempunyai pandangan integral antara duniawi dan ukhrawi. ${ }^{6}$ Lebih jelas W. Montgomery Watt menerangkan bahwa gerakan Nabi Muhammad pada mulanya tidak memiliki relevansi politis yang jelas. Akan tetapi, pada akhirnya gerakan religius nabi ini disegani oleh pedagangpedagang besar di Makkah. Sifat-sifat politis dalam proses penyebaran dan perkembangan Islam ini termanifestasikan dalam piagam madinah. Oleh karenanya gerakan ini mampu menjawab situasi Makkah secara total. sehingga lambat laun memiliki relevansi bagi kegiatan politik di tanah Arab saat itu. ${ }^{7}$

Piagam Madinah yang dimaksudkan di atas dapat dijadikan bukti otentik yang memberikan pengertian kepada kita tentang keterbukaan dan penghormatan kepada sesama manusia. Hal inilah mungkin yang

\footnotetext{
${ }^{6}$ Nurcholis Madjid, Islam: Agama Kemanusiaan (Jakarta:Yayasan Wakaf Paramadina, 1995), 188.

7 W. Montgomery Watt, Islamic Political Thought: The Basic Concepts (Edinburgh: Edinburgh University Press, 1968), 3.
} 
memunculkan pemahaman bahwa Islam sebagai kekuatan politik tidak terlepas dari Islam sebagai gejala teologis.

Dari perjuangan nabi dapatlah dilihat bahwa dari beberapa gerakangerakan beliau memiliki kesamaan dengan unsur dan sifat politik. Hal ini juga penulis jumpai dalam suatu kesempatan diskusi yang disampaikan oleh $\mathrm{KH}$. Said Aqil Sirodj, MA. ${ }^{8}$

\section{Demokrasi: Sebuah Mekanisme Kesetaraan Politik}

Begitu banyaknya ulasan tentang demokrasi memang dapat menimbulkan kesulitan apabila di antara ulasan-ulasan tersebut ada pertentangan. Robert A. Dahl bahkan terkesan memakai pendekatan tesisantitesis-sintesis yang cukup menimbulkan pertanyaan besar ketika mencoba menjelaskan tentang apa sebenarnya demokrasi itu. Semisal, gagasannya tentang poliarki, yang ditempatkannya di atas sebelum demokrasi. Sementara Negara-negara yang dianggap sedah mengalami poliarki pun tidak mengalami apa-apa meskipun dikenal sudah sebagai Negara demokratis."

Akan tetapi dari sekian banyak bahasan tentang demokrasi, kiranya ada saja pokok-pokok yang selalu dibahas sebagai elemen penting yang perlu diupayakan oleh demokrasi, maka dapat disebutkan dibawah ini tentang elemen-elemen demokrasi di atas, yaitu sebagai berikut: ${ }^{10}$

a. Ada pengakuan kesetaraan antara individu

b. Nilai-nilai yang melekat pada individu mengatasi nilai-nilai yang melekat pada Negara

c. Pemerintah merupakan pelayan masyarakat

d. Ada aturan-aturan hukum

e. Ada pengakuan atas nalar, eksperimental, dan pengalaman

f. Ada pengakuan mayoritas atas hak-hak minoritas

g. Ada prosedur dan mekanisme demokratis sebagai cara mencapai tujuan bersama

Dari beberapa prinsip-prinsip demokrasi di atas, kiranya dapat dipahami bahwa demokrasi pada akhimya mengandaikan adanya suatu kesetaraan atau keseimbangan politis. Hal ini Berarti setiap elemen masyarakat memiliki kesempatan dan kemampuan yang seimbang untuk memperjuangkan kepentingan politisnya.

\footnotetext{
${ }^{8}$ Dalam kesempatan tersebut, beliau memberikan kesimpulan bahwa dalam sejarah perjalanan nabi Muhammad terdapat unsur politis ketika Islam disampaikan kepada masyarakat. Sehingga Islam bisa menyebar dengan luas.

${ }^{9}$ Robert A. Dahl, Democracy and its Critics (New Haven and London: Yale University Press, 1989), 213.

${ }_{10}$ Mahmoud Muhammad Thaha, Syariah Demokratik, terj. Nur Rahman (Surabaya: eLSAD, 1996), 232.
} 
Dari paham kesetaraan inilah dapat diturunkan berbagai macam teori demokrasi yang akomodatif bagi gagasan Islam. Artinya, Islam sendiri memiliki basis kuat yang mendukung prinsip kesetaraan tersebut. Seiring dengan gerak rasionalitas dan inklusivisme Islam, Islam dapat memperkuat basis demokratis tersebut dengan syari'ahnya. ${ }^{11}$ Karena Islam bersumber pada al-Qur'an, maka dengannya ada beberapa kaidah-kaidah yang dapat dimungkinkan menjadi legitimasi terhadap demokrasi.

Kaidah pertama disini adalah sebagaimana penjelasan di atas, yaitu demokrasi menginginkan dan mengharapkan adanya kesetaraan. Dalam hal ini kita tahu bahwa pada mulanya misi Islam di dalam penyebarannya yaitu mengentaskan perbedaan-perbedaan yang sangat mencolok dalam tatanan kehidupan masyarakat saat itu.

Kesetaraan dalam berbagai segi adalah prinsip yang paling mendasar dalam sebuah sistem demokrasi. Harun Nasution dan Tahir Azhary misalnya, yang mana mereka mendukung persamaan karakter alamiah (fitrah) manusia. Keduanya mendasarkan argumen tersebut pada al-qur'an surah al-Hujurat: 13, yang memberikan pengertian bahwa Allah menciptakan manusia dari pasangan Adam dan Hawa. Meskipun sekarang ini manusia terdiri dari bermacam-macam bangsa, ras, agama, bahasa, dan warna kulit yang berbea, pada dasarnya mempunyai kedudukannya adalah sama. ${ }^{12}$

Apabila Nurcholish Majid menekankan persamaan dalamwilayah etik dan politik, maka Amin Rais dan Azhary menekankan persamaan pada aspek hukum. Menurut mereka persamaan di muka hukum berarti bahwa hukum harus berlaku bagi semua warga Negara dan harus dipatuhi oleh semua tanpa adanya perbedaan atas dasar latar belakang mereka. ${ }^{13}$

Kaidah selanjutnya adalah didasarkan pada QS. Al-Syura: 38, dan Ali Imran: 159 yang mengungkapkan kewajiban dan arti penting musyawarah (syura) dalam Islam. Prinsip ini rupanya juga diperkuat oleh sumber sekunder syari'ah, yaitu penghayatan yang dilakukan oleh nabi sendiri, dan kaidah musyawarah ini sifatnya inklusif karena terbuka juga bagi kelompok nonmuslim. ${ }^{14}$

Sudah pasti hal yang harus dicatat disini bahwa dalam musyawarah sendiri terkandung beberapa unsur yang ada dalam proses berpolitik, yakni partisipasi, kebebasan menyatakan pendapat, serta persamaan. Sehingga bisa

\footnotetext{
${ }^{11}$ Kuntowijoyo, Identitas Politik Umat Islam (Bandung: Mizan, 1997), 91-105.

${ }^{12}$ Harun Nasution dan Bachtiar Efendy, Hak-bak Azasi Manusia dalam Islam (Jakarta:Pustaka Firdaus dan Yayasan Obor Indonesia, 1978), ix-x, lihat pula Muhammad Tahir Azhary, Negara Hukum: Suatu Studi tentang Prinsip-prinsipnya, dilibat dari Segi Hukum Islam: Implementasinya Pada Periode Madinah dan Masa Kini (Jakarta: Bulan Bintang, 1992), 91/2.

13 Amin Rais, "pengantar" dalam Demokrasi dan Proses Politik (Jakarta: LP3ES, 1986), xix.

${ }^{14}$ Bernard Lewis, Bahasa Politik Islam (Jakarta: PT Gramedia Pustaka Utama, 1994), 194.
} 
disimpulkan bahwa dengan ketiga unsur tersebut maka akan menunjang terlaksananya musyawarah yang berujung pada demokratis.

Tampaknya, sistem dan konsep syura dalam Islam ini tidak ada perbedaan yang signifikan dengan prinsip-prinsip demokrasi. Pada momenmomen tertentu nabi seringkali meminta pendapat-pendapat para sahabat yang tidak disebutkan dalam al-Qur'an. Sifat keluwesan nabi dengan memberi kebebasan berpendapat inilah yang menjadikan ada kesamaan konsep dengan demokrasi.

Mengutip pendapat Billah, Nurcholish Madjid mengatakan bahwa Islam dianggap terlalu modern pada saat itu. Suatu kenyataan yang ditunjukkan oleh tingkat keterlibatan dan partisipasi politik besar oleh anggota masyarakat jelata. Lebih dari itu, masa itu adalah modern dengan adanya keterbukaan rekrutmen terhadap posisi kepemimpinan berdasarkan kemampuan, dan ditandai dengan usaha untuk melembagakan bentuk kepemimpinan yang tidak turun temurun. ${ }^{15}$

Kaidah ketiga yaitu yang mempunyai padanan kata dengan "sabib", disini berarti bahwa baik individu maupun kelompok diupayakan berbuat baik dan memberikan maslahat kepada lainnya. Dalam hal ini berkaitan pula dengan konsep ta'awun atau tolong menolong atau kerjasama yang juga sangat dianjurkan di dalam al-Qur'an maupun sunnah. Maka dari kedua konsep tersebut akan muncul sikap dan sifat yang positif yang nantinya bermuara pada "goodness of public".

Dengan demikian dari beberapa konsep kaidah di atas maka kesemuanya dituntut untuk membawa sebuah perubahan yang diharapkan manusia di setiap zamannya. Dengan begitu perbaikan demi perbaikan yang dilakukan akan berdampak baik bagi kelangsungan hidup manusia.

\section{Islam Vis a Vis Demokrasi}

Sebelum kita menakar nisbah/hubungan antara Islam dan demokrasi, perlu kiranya disini disampaikan bahwa ada beberapa catatan yang harus dipahami. Pertama yaitu bahwa posisi Islam disini tidak dilihat sebagai suatu sistem dengan mengesampingkan unsur-unsur keagamaan lainnya, akan tetapi, Islam yang dimaksudkan adalah dilihat dari segi politisnya. Sedangkan demokrasi sendiri hanyalah sebuah sistem/mekanisme untuk menuju suatu tujuan yang baik dalam hal berbangsa dan bernegara. Maka dari sini dapat disimpulkan bahwa perbandingan antara Islam demokrasi tidak sebanding.

Adalah Nurcholish Madjid yang memberikan tanggapan bahwa Islam dan demokrasi tidak dapat dibandingkan dalam tataran yang setingkat,

${ }^{15}$ Nurcholish Madjid, Kaum Miskin dan Partisipasi Sosial Politik: Masalah Hak-hak Individual yang Tak Teringkari, dalam Nurcholish Madjid, Islam Doktrin dan Peradaban: Sebuab Telaah Kritis tentang Masalah Keimanan, Kemanusiaan dan Kemodernan (Jakarta: Yayasan Wakaf Paramadina, 1992), 560. 
sehingga perlu diakui adanya hubungan sub-ordinatif dalam paradigma Islam. Pola hubungan sub-ordinat ini menempatkan Islam sebagai substansi mutlak sedangkan negara menjadi relatif. Di hadapan negara, Islam bersifat mutlak dalam arti bahwa negara dapat menjadi ekspresi nilai-nilai perenial Islam. ${ }^{16}$

Hal semacam ini menurut penulis menjadi ranah perdebatan antara Islam dan Negara yang sudah berlangsung lama. Untuk itu, menghindari adanya pembahasan yang serupa dan bersifat mengulang-ulang maka hemat penulis kita kembali ke pokok permasalahan tentang relasi/hubungan/nisbah. Maka hubungan antara demokrasi dan Islam disini adalah memiliki keterkaitan dan sifat yang menyerupai satu sama lain. Demokrasi muncul sebagai hasil olah pikir manusia yang membuka peluang besar bagi perubahan nilai oleh masyarakat.

Kiranya letak potensi pertentangan antara Islam dan demokrasi, yaitu ketika gagasan-gagasan teologis dalam Islam sendiri berhadapan dengan gagasan demokrasi-yang dapat dipastikan tidak dilandasi perwahyuan transedental. Kasus Mohammed Thaha-yang dihukum gantung karena menyuarakan hak untuk berpindah agama-dapat menjadi contoh jelas untuk menggambarkan betapa institusi keagamaan, biar bagaimanapun juga memiliki sistem kepercayaan yang dapat bertentangan dengan gagasan demokrasi. ${ }^{17}$

Catatan selanjutnya yaitu dari sudut demokrasi sendiri yang belum memiliki pengertian yang disetujui bersama dan bersifat baku. Sehingga dapat dikatakan bahwa demokrasi compatible dengan Islam. Hal ini memberikan ruang gerak bagi Islam untuk memaknai demokrasi. Sedangkan member makna kepada demokrasi berarti telah menginklusikan demokrasi dalam Islam atau lebih tepatnya member warna Islamiah pada demokrasi.

Mengutip pendapat Fazlur Rahman, Hasbi Amiruddin mengatakan bahwa Islamlah yang mengajarkan demokrasi murni, bukan Barat. ${ }^{18}$ Akan tetapi dalam kesempatan yang berbeda pendapat Afan Gaffar menjelaskan tentang demokrasi "secara utuh" bukanlah gagasan Islam, bahkan kosa kata politik Islam sendiri sebenarnya tidak mengenal kata demokrasi. ${ }^{19}$ Disini hemat penulis kosa-kata demokrasi memang tidak dilahirkan oleh Islam, akan tetapi ia berasal dari luar Islam. Namun yang juga perlu diketahui adalah

${ }^{16}$ Nurcholis Madjid, Islam: Agama..., 36.

17 Ahmad Suaedy, et.al, Spiritualitas Baru: Agama dan Aspirasi Rakyat (Yogyakarta: Institut Dian/Interfidei, 1994), 271.

${ }^{18}$ Hasbi Amiruddin, Konsep Negara Islam menurut Faz̨lur Rahman (Yogyakarta: UII Press, 2006), 109-117.

${ }^{19}$ Afan Gaffar, Islam dan Demokrasi: Pengalaman Empirik yang Terbatas dalam Muh. Wahyuni nafis, et.al., Kontekstualisasi Ajaran Islam: 70 Tahun Prof. Dr. H. Munawir Sadzali, MA (Jakarta: IPHI dan Yayasan Wakaf Paramadina, 1995), 347. 
nilai-nilai yang terkandung dalam demokrasi itu sudah terangkum dan populer dikalangan muslim. Sehingga demokrasi dan Islam disini masih memiliki keterkaitan dan keberhubungan satu sama lain.

Ada beberapa Negara dan atau bahkan kalangan muslimin sendiri yang menentang dan menolak keras sistem demokrasi dengan berbagai macam alasan. Sebenarnya letak konflik tersebut bisa dimungkinkan berasal dari antara Islam dan kekuatan politis lain, namun itu bukan antara Islam dan demokrasi. Bagaimanapun juga Islam dan demokrasi memiliki hubungan erat sehingga dapat dikatakan bahwa Islam compatible dengan demokrasi atau sebaliknya. "Syari'ah demokratis" telah memberi legitimasi dan ruang pada "demokrasi konvensional" sehingga bisa dikatakan sebagai sistem gagasan yang Islami.

Selain itu, secara historis, Islam sendiri memiliki tradisi yang menunjukkan ciri-ciri demokrasi. Keadaan bahwa kepemimpinan ditetapkan atas dasar ability and capability, proses pemilihan terbuka, hak dan kewajiban yang sama sebagai rakyat, pengakuan hak kepada agama lain. Maka hal ini sungguh telah menunjukkan keunggulan Islam sebagai kekuatan politik yang luar biasa pada masanya. ${ }^{20}$ Keadaan semacam ini menjadi salah satu contoh bagaimana Islam masa awal mewujudkan nilai-nilai demokrasi yang diseruserukan orang saat ini.

Dalam teknis pelaksanaannya, variasi akan terjadi dimana-mana sehingga memang tidak dapat ditentukan model Negara demokrasi yang akurat. Dengan demikian, Islam dapat masuk dan berinteraksi dengan istilah demokrasi, sehingga menjadikan Islam sendiri mampu menyaingi sistem ketatanegaraan modern, yakni demokrasi.

Untuk menjawab tantangan dan perubahan zaman terkait dengan hal tersebut di atas, maka Islam perlu merumuskan kembali pandanganpandangan terhadap-semisal- sekularisasi, martabat manusia, plurasisasi, solidaritas, semangat berbangsa dan bernegara, kerjasama antar agama, dan masih banyak lagi unsur-unsur kebaruan yang lain sesuai dengan berubahnya suatu masa.

Termasuk pula di dalamnya, Islam juga perlu menjadi terbuka untuk memegangsyari'ah secara wajar. Dalam arti bahwaa sumber-sumber syari'ah itu perlu dilihat secara proporsional. Maka dengan demikian dapatlah ditemukan mana yang sungguh-sungguh perennial, spasial, dan temporal. ${ }^{21}$ Sehingga usaha-usaha Islam dalam menghadapi tantangan zaman sebagaimana di atas akan menghindarkannya dari stagnasi dan arogansi.

${ }^{20}$ Nurcholis Madjid, Islam: Agama..., 188.

${ }^{21}$ Djohan Effendi dan Ismed Natsir, Pergolakan Pemikiran Islam: Catatan Harian Ahmad Wabib (Jakarta: LP3ES, 1981), 26. 
Usaha reinterpretasi terhadap Islam atau membuat semacam keterbukaan dalam hal inovasi baru juga akan memantapkan kekuatan politik Islam baik dalam tataran teori maupun dalam implementasinya. Secara teoritis dapat disimpulkan bahwa Islam tetap memandang demokrasi sebagai bagian penting dari sebuah peradaban manusia. Karena itu, secara teoritis hubungan Islam dan demokrasi bersifat positif, dan antara satu dengan lainnya dapat dikoordinasikan.

\section{Praktik Islam Demokratis}

Lain soal jika pola hubungan Islam dan demokrasi dipandang dari segi politik praktis. Kadang kala yang terjadi justru syari'ah yang non-demokratis yang menonjol. Setidak-tidaknya penghayatan syari'ah itu tidak sesuai dengan semangat demokrasi. ${ }^{22}$

Dalam praktik sehari-hari, agaknya Islam demokratis bukanlah realitas semu dikalangan grass-root. Nilai-nilai demokratis sudah dihayati oleh kelompok besar Islam. Kalaupun pada kenyataanyya suasana demokrasi itu tidak ada dalam percaturan politik di Indonesia, itu berarti bahwa di tingkst elitlah Islam mengalami kemacetan. ${ }^{23}$

Dengan mengandaikan bahwa budaya politik demokratis lahir dari atas, kiranya dapatlah ditegaskan tentang perlunya konsolidasi di tingkat elit Islam. Tentu saja karena ragamnya elit islam disini, konsolidasi menjadi sesuatu yang tidak mudah dan cepat untuk dilaksanakan. Maka disinilah terlihat akan pentingnya sebuah dialogis yang di dalamnya tidak hanya sesuatu yang bersifat teologis semata, namun juga perlu memasukkan unsureunsur politis.

Deskripsi-deskripsi di atas sepertinya sesuai dengan istilah "koalisi" yang sudah menjadi agenda setiap partai politik di Indonesia ketika menghadapi musim pemilu. Dengan demikian masuknya Islam atau partai Islam dalam kegiatan semacam ini akan memiliki peluang untuk mewujudkan syari'ah demokratis. Pun juga sambil mengembangkan Islam demokratis. Sehingga dapat dikatakan bahwa jalan menuju demokrasi bagi Islam adalah jalan yang panjang, dan harus terbuka dengan pembaharuan-pembaharuan lainnya.

\section{Hubungan Islam dan Demokrasi dalam Pandangan Abdullahi Ahmed an-Na'im}

\section{Sketsa Biografi}

Abdullahi Ahmed an-Na'im adalah seorang aktivis HAM yang dikenal di dunia Internasional. Abdullah lahir pada 6 April 1946 (walaupun dalam

\footnotetext{
22 Suaedy, Spiritualitas..., 273.

23 Arief Afandi, Islam: Demokrasi Atas Bawah (Yogyakarta: Pustaka Pelajar, 1997), 118.
} 
Akte kelahirannya tercatat 19 November 1946), di Desa al-Maqa>wier, Tepi Barat Nile $200 \mathrm{~km}$ dari Utara Khartoum. Ia merupakan anak pertama dari sebelas bersaudara yang berasal dari pasangan Ahmed al-Na'im dan Aisha alAwad Osman. Ayahnya bernama Ahmed, dan keluarganya berasal dari wilayah Sudan Utara yang pernah menjadi wilayah Nubia kuno yang memeluk agama Kristen Koptik sekitar abad ke-5 M, sebelum akhirnya memeluk agama Islam yang percakapannya menggunakan bahasa Arab selama abad ke-13 dan $14 \mathrm{M}^{24}$

Sebagaimana negara-negara Islam lainnya, sudan memilki permasalahan internal yang sulit dipecahkan. Permasalahan dasar yang dihadapi sudan dan Negara-negara Islam pada umumnya setelah mencapai kemerdekaannya, adalah bagaimana membangun hubungan antara Islam dengan Negara. Seperti halnya turki, Mesir, Pakistan, aljazair dan Indonesia. Sudan mengalami kesulitan upaya tersebut, bahkan mengalami permusuhan dan ketegangan politik yang tajam dan belum selesai hingga sekarang. untuk mendefinisikan Islam dalam kenegaraan modern, Negara-negara Islam ketika itu mempunyai tiga pilihan: Islam, sekuler, dan muslim (Negara berpenduduk muslim). ${ }^{25}$

Dari latar belakang intelektualnya, Abdullahi ahmed an-Na'im mengenyam pendidikan mulai dari tingkat dasar dan menengah atas, kemudian melanjutkan studi S-1 pada fakultas hukum, jurusan hukum pidana di universitas Khartoum, Sudan dan memperoleh gelar LL.B dengan predikat cumlaude. ${ }^{26}$

An-Na'im melanjutkan studi program pascasarjana (S2) di Universitas Cambridge Inggris pada tahun 1971, dengan mengambil spesialisasi tentang hak-hak sipil dan hubungannya dengan konstitusi Negara-negara berkembang dan hukum internasional (The Law Relating to Civil Liberties, Constitutional Law Developing Countries dan Private International Law). Dari perguruan ini an-naim berhasil memperoleh gelar LL.M. ${ }^{27}$

Sedangkan untuk program doktor (Ph.D), ditempuh oleh an-Naim di universitas Edinburg, skotlandia dalam bidang hukum pada tahun 1976, dengan disertasi mengenai perbandingan prosedur pra-peradilan criminal antara hukum Inggris, skotlandia, amerika serikat dan sudan (Comparative Pretrial Criminal Procedure: English, Scottish, U.S and Sudanese Law).

\footnotetext{
${ }^{24}$ Moh. Dahlan. 'Abdullah Ahmed al-Na'im Epistemologi Hukum Islam. (Yogyakarta: Pustaka Pelajar, 2009), 43. Lihat juga pada Muhyar Fanani, Abdullabi Ahmed Na'im; Paradigma Baru Hukum Public Islam dalam Pemikiran Kontemporer (Yogyakarta: jendela, 2003), 3.

25 Adang Djumhur Salikin, Reformasi Syariah dan HAM dalam Islam, Bacaan Krtitis terhadap Pemikiran al-Na'im (Yogyakarta: Gama Media, 2004), 36.

26 Tholhatul Choir, Ahwan Fanani, Islam dalam Berbagai Pembacaan Kontemporer. Cet.I

(Yogyakarta: Pustaka Pelajar, 2009), 330.

${ }^{27}$ Salikin, Reformasi Syari'ah ..., 19-20.
} 
Selama menekuni ilmu hukum, khususnya bidang hukum publik, secara akademisi an-Na'im menerima pengaruh dari guru-gurunya, terutama pada bidang keilmuan yang ditekuninya itu. Sepanjang proses tersebut, anNa'im juga sering mengadakan kontak intelektual dengan para pemikir keagamaan, baik yang modern maupun tradisional, baik ketika belajar di Sudan maupun selama dan sesudah belajar di luar negeri. Di antara tokoh pemikir muslim yang sangat berpengaruh pada pemikiran an-Na'im adalah Mahmoud Muhammed Taha, pendiri dan tokoh sentral Partai Persaudaraan Republik (The Republican brotherhood). Sang guru inilah yang memberikan dasar pijakan pemikiran hukum Islamnya, bahkan an-Na'im praktis hanya menerjemahkan pemikiran sang guru ke dalam materi-materi hukum yang lebih konkret.

Selain telah membina karir kesarjanaan, an-na'im aktif pula dalam masalah sosial politik dan keagamaan yang tengah terjadi di negaranya Sudan, bersama guru dan kelompoknya. An-na'im melakukan gerakan oposisi terhadap pemerintah yang ketika itu dibawah pimpinan jenderal mohammad ja'far numeiri (1969-1985). Gerakan ini mencapai puncaknya ketika rezim numeiri melakukan islamisasi dengan memberlakukan hukum Islam (Islamic law). Sebagai hukum Negara dari hasil penafsirannya sendiri tahun 1983 yang menggoyahkan kebijakan yang represif di seluruh negeri. ${ }^{28}$

Meski berasal dari negeri miskin dan terbelakang, an-Na'im mampu menjadi akademisi bertaraf Internasional yang sukses, Ia telah melahirkan berbagai karya ilmiah, di antaranya Toward An lslamic Reformation; Civil Liberties, Human Rights, and International Law yang diterbitkan oleh Syracuse, N.Y: Syracuse University Press, 1990 yang merupakan karya monumental. Buku ini membedah aspek-aspek ambiguitas pemikiran hukum Islam, baik persoalan metodologi maupun materinya. Di samping itu, karya-karya anNa'im masih tersebar di berbagai tempat, baik berupa buku maupun artikel. ${ }^{29}$

Di tengah-tengah kesibukan aktivitas sehari-harinya, Beliau banyak sekali melakukan penelitian dan menulis berbagai topik yang berkaitan dengan status, aplikasi dan pembaruan internal hukum Islam. ${ }^{30}$ Banyak yang mengenal an-Na'im bahwa beliau termasuk ilmuan yang memiliki komitmen yang kuat terhadap Islam sekaligus mempunyai dedikasi yang tinggi untuk menegakkan HAM. Selain sebagai ahli hukum an-Na'im juga seorang yang ahli dalam bidang hubungan Internasional. ${ }^{31}$

28 Husniatus Salamah Zaniati, "reformasi Syari'ahdan hak-hak asasi manusia (kajian atas pemikiran Abdullah ahmed an-na'im)" jurnal IAIN Sunan Ampel, no. 1931 (1999), 68.

${ }^{29}$ Moh. Dahlan. 'Abdullah Ahmed ..., 44.

30 Tholhatul Choir, Ahwan Fanani, Islam dalam Berbagai Pembacaan Kontemporer..., 330.

${ }^{31}$ Khudori Sholeh, Pemikiran Islam Kontemporer, (Yogyakarta: Jendela, 2003), 3-5. 


\section{Metodologi Pemikiran An-Na'im}

Setiap tokoh pasti memiliki ciri dan karakter tersendiri dalam merumuskan pemikiran yang merupakan hasil dari pemahaman masing-masing, Model paradigma barunya an-Na'im, beliau berpendapat bahwa syariah tidak cukup hanya dengan reformasi hukum Islam akan tetapi lebih dari itu yaitu dengan rekonstruksi, reaktualisasi atau bahkan mungkin harus dengan dekonstruksi. Karena Islam lahir dalam setting masyarakat yang sama sekali berbeda dengan masyarakat kontemporer yang tengah berlangsung dalam kehidupan modern saat ini.

An-Na'im membangun metodologi dengan teori yang selama ini baru. Hukum Islam harus direkonstuksi secara total, agar bisa koheren dengan modernitas, namun tetap Islam. Pemikiran dekonstuktifnya an-Na'im cenderung skeptipis dan apatis terhadap metodologi yang telah ada sebelumnya yaitu fiqh klasik. 32

Menurut Na'im, hukum Islam mengalami dilema yang cukup serius dengan konstitusionalisme, hukum pidana, serta hubungan internasional dan HAM. Karena itu, empat bidang sasaran itulah yang menjadi proyek pembaruan hukum Islam versi an-Na'im. Reformasi hukum Islam menurutnya merupakan satu-satunya cara untuk menyelesaikan dilema ini, agar syari'ah Islam bisa eksis dan sejalan dengan kehidupan modern. ${ }^{33}$

Selanjutnya an-Na'im mengambil metode gurunya, yaitu metodologi pembaharuan yang revolusioner, yang digambarkan sebagai evolusi legislasi Islam (modern mystical approach), yang intinya suatu ajakan untuk membangun prinsip penafsiran baru yang memperbolehkan penerapan ayat-ayat alQur'an dan Sunnah. Pendekatan ini jika diterapkan akan mampu memecahkan kebuntuan antara tujuan pembaruan, keterbatasan konsep dan teknik syari'ah historis.

Prinsip naskh pembatalan teks al-Qur'an dan Sunnah tertentu untuk tujuan-tujuan penetapan hukum oleh teks-teks al-Qur'an dan Sunnah untuk tujuan-tujuan penetapan hukum oleh teks al-Qur'an dan Sunnah yang lain sangat menentukan bagi validitas teoritik dan kelangsungan praktek dari pendekatan evolusioner. Kemudian memadukan teori naskh tersebut dengan prinsip-prinsip umum tentang analisa kongkret terhadap implikasi-implikasi hukum publik Islam. Utamanya terhadap keseimbangan hak-hak muslim dan non-muslim serta laki-laki dan perempuan dalam menentukan nasib sendiri. Inilah harga kemanusian yang tertimbun dalam formulasi teoritik syari'ah tradisional.

\footnotetext{
32 Moh. Nur Hakim, Abdullah Abmad An-Naim: Dekontruksi Hukum Publik Islam, dalam NeoModernisme dalam Islam (Malang: UMM press: 2001), 146.

33 Abdullahi Ahmed an-Na'im, Dekonstruksi Syari'ab: Wacana Kebebasan Sipil, Hak Asasi Manusia dan Hubungan Internasional dalam Islam, terj. Ahmad Suaedy dan Amiruddin Ar-Rani, (Yogyakarta: LkiS, 1997), 3.
} 


\section{Abdullahi Ahmed an-Na'im Berbicara tentang Islam dan Demokrasi}

Berawal dari konsep nasakh terbalik yang dipopulerkan oleh gurunya Muhammad Taha, an-Na'im mencoba untuk mengimplementasikan teori tersebut pada tataran HAM, termasuk di dalamnya adalah yang bersifat konstitusionalisme modern. Dalam pemahamannya, ia menawarkan konsep baru kepada Islam yang nantinya bisa bersandingan hukum konstitusional.

Sebagai premis awal penulis, an-Na'im disini gencar mendemonstrasikan syari'ah yang harus mengidentifikasi prinsip-prinsip dan aturan-aturan syari'ah untuk disesuaikan dengan perkembangan isu hukum konstitusional. Disamping itu pula ia menegakkan dengan gigih bendera HAM secara komprehensip bagi semua manusia tak terkecuali umat Islam itu sendiri. ${ }^{34}$

An-Na'im mengajukan konsep perubahan dalam hukum publik di Negara-negara Islam dengan membangun suatu versi hukum publik Islam yang sesuai dengan standar konstitusionalisme, hukum pidana, hukum internasional dan hak-hak asasi manusia modern.

Menurut an-Na'im, konsep konstitusionalisme modern dan implikasinya ini telah diartikulasikan dan diaplikasikan secara sangat baik di Negara-negara Barat. Namun disini penulis mengapresiasi lanjutan pendapatnya yang mengatakan bahwa mekipun demikian, tidak berarti bahwa konstitusionalisme Barat merupakan konstitusionalisme yang ideal untuk ditiru dan diterapkan begitu saja oleh umat Islam atau masyarakat lainnya. ${ }^{35}$ Meskipun demikian, kiranya dari situ umat Islam dan masyarakat lain dapat mengambil dan mengadaptasinya, yang tentunya disesuaikan dengan agama dan tradisi kultural yang dimiliki.

Terlepas dari itu, an-Na'im mengakui bahwa Islam sudah mengakui sifat-sifat demokrasi. Ia mencontohkan dengan proses pemilihan khalifah juga didasarkan dan dipilih oleh sekelompok kecil kaum Muslim kemudian dikuatkan oleh masyarakat muslim melalui dukungan umum (bay'at). Namun akhirnya terjadi kemerosotan dengan penunjukan langsung yang bersifat turun temurun. Hal ini disebabkan karena ketidakjelasan dasar legitimasi politik dan informalitas prosedur di bawah negara model Madinah. ${ }^{36}$

Bukti lainnya adalah berkaitan dengan kedaulatan, bahwa masingmasing dan setiap warga negara dalam suatu Negara harus memiliki jalan yang secara signifikan mempengaruhi proses-proses penentuan kebijakan dan legislasi hukum. Maka disinilah letak sifat demokrasi itu sendiri, yaitu

\footnotetext{
${ }^{34}$ Abdullahi Ahmed an-Na'im, Dekonstruksi Syari'ah..., 133.

35 Ibid., 134.

${ }^{36}$ Ibid., 146.
} 
memberikan "kebebasan" kepada setiap warga Negara untuk mengutarakan pendapat dan kontribusinya terhadap negaranya. ${ }^{37}$

Terlihat sekali bahwa menurut Na'im, demorasi dalam Islam adalah suatu sistem pemerintahan yang sejatinya telah ada pada masa-masa awal Islam. Meskipun demikian istilah demokrasi tidak secara tegas dideklarasikan oleh umat muslim sendiri. Sehingga tidak dapat dipungkiri bahwa Islam telah lebih dulu mempraktikkan konsep-konsep demokrasi secara umum.

\section{Penutup}

Hubungan Islam dan demokrasi di atas sangat memberikan deskripsi dan pemahaman yang positif, khususnya bagi penulis sendiri. Materi tentang Islam dan demokrasi selalu memiliki keterkaitan pembahasan dengan agama -yang dalam hal ini adalah Islam- dan negara.

Dapat digaris bawahi bahwa demokrasi kemungkinan besar bukan berasal dari kosa-kata Islam. Meskipun demikian, dalam kenyataannya Islam dan demokrasi terdapat beberapa titik persamaan sehingga antara keduanya seakanakan ada keterkaitan yang sangat erat.

Di antara nilai-nilai Islamiah yang terhubung dan serupa dengan kaidahkaidah demokrasi yang telah dibahas di muka yaitu tentang konsep persamaan, kesetaraan, kerjasama, unsur perubahan, perbaikan, dan lain sebagainya. Meskipun pada dasarnya kata demokrasi belum memiliki kinerja yang baku dalam taraf implementasinya, sehingga memunculkan banyak tafsir. Maka dari sini Islam masuk dan mencoba memberikan nuansa Islam dalam demokrasi yang sudah banyak dikenal lahirnya dari Yunani.

Syari'ah dipahami oleh an-Na'im sebagai hasil dari interpretasi generasi muslim awal kemusian dikembangkan dengan tujuan untuk menjawab wacana kontemporer seperti keadilan, demokrasi, kebebasan manusia sebagai individu dan kewajibannya terhadap lingkungan. An-Na'im melegitimasi bahwa Islam sudah mengenal kaidah-kaidah demokrasi secara umum. Meskipun pada dasarnya kata demokrasi itu sendiri dikenal lahir dari dunia Barat.

Pandangan An-Na'im terhadap demokrasi dalam sistem pemerintahan muslim sangat mungkin untuk dilakukan. Hal ini disebabkan karena banyaknya prinsip-prinsip Islam yang terkandung dalam demokrasi. Demikian pula sebaliknya, demokrasi pada kenyataannya telah mengadopsi nilai-nilai luhur dalam Islam. Sehingga dengan demikian dapat ditarik sebuah kesimpulan bahwa antara Islam dan demokrasi memiliki hubungan keterkaitan yang sangat erat.

37 Ibid., 151-159. 


\section{Daftar Pustaka}

Afandi,Arief. Islam: Demokrasi Atas Bawah. Yogyakarta: Pustaka Pelajar, 1997.

Amiruddin, Hasbi. Konsep Negara Islam menurut Fazlur Rahman. Yogyakarta: UII Press, 2006.

Al-Anshari. Fauzan, Presiden Indonesia untuk Penegakan Syariat Islam. Jakarta: Panitia Persiapan Kepemimpinan Nasional, 2007.

Azhary, Muhammad Tahir. Negara Hukum: Suatu Studi tentang Prinsip-prinsipnya, dilibat dari Segi Hukum Islam: Implementasinya Pada Periode Madinah dan Masa Kini. Jakarta: Bulan Bintang, 1992.

Choir, Tholhatul. Ahwan Fanani, Islam dalam Berbagai Pembacaan Kontemporer. Cet.I. Yogyakarta: Pustaka Pelajar, 2009.

Dahlan. Moh. Abdullah Ahmed al-Na'im Epistemologi Hukum Islam. Yogyakarta: Pustaka Pelajar, 2009.

Dahl, Robert A. Democracy and its Critics. New Haven and London: Yale University Press, 1989.

Effendi, Djohan dan Ismed Natsir. Pergolakan Pemikiran Islam: Catatan Harian Ahmad Wabib. Jakarta: LP3ES, 1981.

Fanani, Muhyar. Abdullabi Ahmed Na'im; Paradigma Baru Hukum Public Islam dalam Pemikiran Kontemporer. Yogyakarta: jendela, 2003.

Gaffar, Afan. Islam dan Demokrasi: Pengalaman Empirik yang Terbatas dalam Muh. Wahyuni nafis, et.al., Kontekstualisasi Ajaran Islam: 70 Tahun Prof. Dr. H. Munawir Sadzali, MA. Jakarta: IPHI dan Yayasan Wakaf Paramadina, 1995.

Hakim, Moh. Nur. Abdullah Ahmad An-Naim: Dekontruksi Hukum Publik Islam, dalam Neo-Modernisme dalam Islam. Malang: UMM press: 2001.

Harun Nasution dan Bachtiar Efendy, Hak-bake Azasi Manusia dalam Islam. Jakarta: Pustaka Firdaus dan Yayasan Obor Indonesia, 1978.

Hilmy, Masdar. Islamism and Democracy in Indonesia: Piety and Pragmatism Singapore: ISEAS, 2010.

Hilmy, Masdar. Islam, Politik \& Demokrasi. Surabaya: Imtiyaz, 2014.

Kuntowijoyo. Identitas Politik Umat Islam. Bandung: Mizan, 1997.

Lewis, Bernard. Bahasa Politik Islam. Jakarta: PT Gramedia Pustaka Utama, 1994.

Madjid, Nurcholish. Kaum Miskin dan Partisipasi Sosial Politik: Masalab Hak-bak Individual yang Tak Teringkari, dalam Nurcholish Madjid, Islam Doktrin dan Peradaban: Sebuah Telaab Kritis tentang Masalah Keimanan, Kemanusiaan dan Kemodernan. Jakarta: Yayasan Wakaf Paramadina, 1992.

Madjid, Nurcholis. Islam: Agama Kemanusiaan. Jakarta:Yayasan Wakaf Paramadina, 1995.

Muhammad Thaha, Mahmoud. Syari'ah Demokratik, terj. Nur Rahman. Surabaya: eLSAD, 1996. 
Na'im (an), Abdullahi Ahmed. Dekonstruksi Syariab: Wacana Kebebasan Sipil, Hak Asasi Manusia dan Hubungan Internasional dalam Islam, terj. Ahmad Suaedy dan Amiruddin Ar-Rani. Yogyakarta: LkiS, 1997.

Rais, Amin. "pengantar" dalam Demokrasi dan Proses Politik. Jakarta: LP3ES, 1986.

Salikin, Adang Djumhur. Reformasi Syariah dan HAM dalam Islam, Bacaan Krtitis terbadap Pemikiran al-Na'im. Yogyakarta: Gama Media, 2004.

Sholeh, Khudori. Pemikiran Islam Kontemporer. Yogyakarta: Jendela, 2003.

Sulaiman,Sadek Jawad. Demokrasi dan Syura dalam wacana Islam Liberal, Pemikiran Islam Kontemporer tentang Isu-isu Global. Jakarta: Paramadina, 2003.

Suaedy, Ahmad. et.al, Spiritualitas Baru: Agama dan Aspirasi Rakyat. Yogyakarta: Institut Dian/Interfidei, 1994.

Watt, W. Montgomery. Islamic Political Thought: The Basic Concepts. Edinburgh: Edinburgh University Press, 1968. 